\title{
Virulence gene profile and antimicrobial resistance of Staphylococcus aureus isolated from bovine mastitis in Kashmir, India
}

\author{
Nazima Nazir*, Shakil Ahmed Wani, Qazi Nyrah, Shaheen Farooq, Mir Nadeem Hassan \\ and Zahid Amin Kashoo
}

Division of Veterinary Microbiology and Immunology, Faculty of Veterinary Sciences and Animal Husbandry Sher-e-Kashmir University of Agricultural Sciences \& Technology, Kashmir Shuhama Campus, Srinagar- 190006 (J\&K), INDIA

*Corresponding author. E-mail: nazimanazir11@gmail.com

Received: June 22, 2016; Revised received: January 24, 2017; Accepted: April 28, 2017

\begin{abstract}
The Staphylococcus aureus is often responsible for a number of diseases in humans and animals, and it is considered as a main etiological agent of bovine mastitis. The pathogenicity of $S$. aureus is due to both its ability to resist antibiotics, and the production of toxins. This study investigated virulence genes, prevalence and antibiogram profile of $S$. aureus isolated from dairy cows suffering from mastitis in the Kashmir. A total of $70 S$. aureus isolates were obtained from 250 mastitic milk samples collected from both organized (47/150) and unorganized $(23 / 100)$ dairy farms. Five pathogenic factors including clfA, hld, seo, lukM, and coa and one resistance gene mecAgene were checked through PCR. Clumping factor gene (clfA) was found in most of the isolates with a percentage of $81.42 \%$ whereas, $h / d$, seo, lukM, and coa were present in $61.2,54.28,70$, and 71 percent of isolates, respectively. However, amplification of coagene yielded DNA bands of two different sizes. A high percentage of antimicrobial resistance rates were observed, wherein, Ampicillin showed highest resistance with $85.7 \%$, followed by Kanamycin, Cefotaxime, Sulphadizine and Streptomicin showing $71.42 \%, 54.28 \%, 51.48 \%$ and $42 \%$, respectively. A high frequency of Methicillin resistant S. aureus (MRSA $28.57 \%$ ) was observed in these isolates and all methicillin resistant isolates were found to be positive for mecA gene via PCR amplification. These results revealed that mastitis-associated $S$. aureus among bovines of Kashmir is able to accumulate different virulence factors and resistance to antimicrobials, making the treatment of infections difficult.
\end{abstract}

Keywords: Antibiogram, Genotypic characterization, Mastitis, PCR, Staphylococcus aureus

\section{INTRODUCTION}

India is the largest milk producer of the world producing 121.8 million tons of milk per annum from 199.1 million cattle and 105.3 million buffaloes which accounts for about 17 per cent of total global production (NDDB, 2012). Despite the high growth rate in production, the average milk yield of cows and buffaloes has remained low. One of the main reasons for low productivity of milk is mastitis, which is single largest problem in dairy animals in terms of economic losses in India. In India overall losses due to mastitis is estimated at Rs. 7165.51 crores (Bansal and Gupta, 2009). It is reported that the annual economic losses due to bovine mastitis has increased 114 folds in about 4 decades from 1962 (INR 529 million/annum) (Dhanda and Sethi., 1962) to 2001 (INR 60532 million/annum) (Dua, 2001).

$S$. aureus has a capacity to produce a large number of potential virulence factors, including a variety of exotoxins and cell surface-associated proteins (Kalorey et al., 2007). The identification of virulence factors is an important step in elucidation of disease process. The pathogenic potential of $S$. aureus depends on numerous cell surface virulence factors and it has capability of producing a variety of exotoxins and cell surfaceassociated proteins that enhances the cellular attachment, organism invasion to host immune system and stimulation of toxic tissue reactions (Hussain et al., 2012). S. aureus secretes various cytotoxins like leukocidins and haemolysins which are responsible for the lesions observed during the development of the infection (Dinges et al., 2000).

In addition to the virulent factors the evolution of antibiotic resistance in $S$. aureus strains is a serious cause of concern in dairy animals (Wang et al., 2008). The $S$. aureus acquires antibiotic resistance with remarkable proficiency (Booth et al., 2001). Strains of $S$. aureus resistant to $\beta$-lactam antibiotics are known as methicillin-resistant $S$. aureus (MRSA). These strains in intra-mammary dissemination often produce incurable severe intra-herd infections (Kumar et al., 2010). The MRSA strains have been observed to be multidrug resistant, especially to aminoglycosides, macrolides, lincosamides, streptogramins, tetracyclines, 
Nazima Nazir et al. / J. Appl. \& Nat. Sci. 9(2): 893 - 898 (2017)

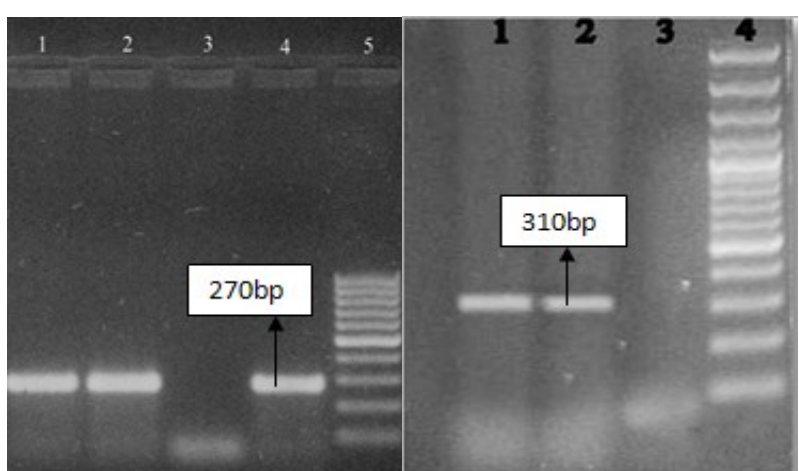

Fig. 1. Agarose gel electro- Fig. 2. Agarose gel electrophoresis PCR amplification phoresis PCR amplification of nuc gene. Lane 1 and 2: of mecA gene Lane 1: PosiPositive samples, Lane 3: tive control, Lane 2: Positive Negative control, Lane 4: sample, Lane 3: Negative Positive control, Lane 5: 100 control, Lane 4: 100 bp DNA bp DNA Marker. Marker.

which are often used in the treatment of mastitis (Kumar et al., 2010). The transmission of bovine MRSA to humans is possible and may contribute to outbreaks in human populations (Lee, 2003).

The identification and characterization of virulence factors of $S$. aureus causing bovine mastitis will enhance our understanding of the pathogenesis of intramammary infection. In addition, the antibiogram of $S$. aureus needs to be studied which would indicate the pattern of resistance to various antibacterials contributing to their virulence properties. These may in turn contribute to the development of methods to minimize the production losses due to mastitis. Further, the study of evolution of strain-specific transmission and virulence characteristics including antibiotic resistance in $S$. aureus isolated from bovine mastitis may help us to understand mechanisms behind emergence of new strains or shifts in mastitis epidemiology in response to control measures, including antibiotic treatment and vaccination. Keeping in view the above facts the objective of this study was to determine the genotypic characterization and antibiogram of S.aureus isolated from milk of cows suffering from mastitis in Kashmir.

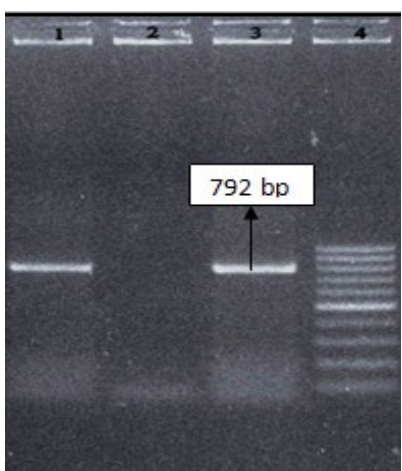

Fig 3. Agarose gel electrophoresis PCR amplification of lukM gene Lane 1: Positive samples, Lane 2: Negative control, Lane 3: Positive control, Lane 4: 100 bp DNA Marker.

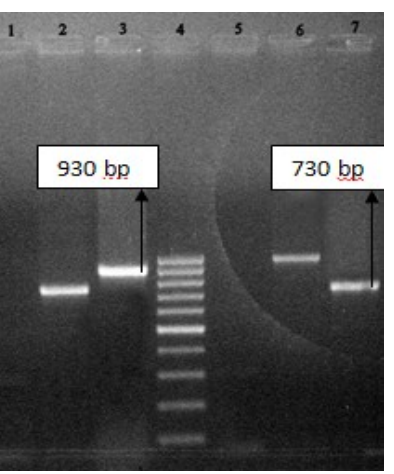

Fig. 4. Agrose gel electrophoresis of PCR amplicon of coagene of $S$. aureus isolates. Lane 1:Negative controlLane 2:Positive control
for coa(710bp), Lane 3: for coa(710bp), Lane 3:
Positive for coa(970 bp), Lane 4. DNA marker Lane. 5: Negative control Lane,6: Sample positive for coa 970 bp), Lane 7: Sample positive for coa $(710 \mathrm{bp})$.

\section{MATERIALS AND METHODS}

Sample collection: A total of 250 mastitic milk samples were collected from organised and unorganized farms in Kashmir. The samples were collected in sterile test tubes and brought to the laboratory on ice in a cool box and processed within two hours of collection.

Isolation and confirmation: For isolation, samples were inoculated in nutrient broth and incubated at $37^{\circ}$ $\mathrm{C}$ for $24 \mathrm{hr}$. Enriched samples were streaked on nutrient agar (Himedia) plates and the plates were incubated at $37{ }^{\circ} \mathrm{C}$ for $24-48 \mathrm{hr}$. After incubation suspected colonies were sub cultured on the nutrient agar until they were free from contaminating bacteria. After incubation suspected colonies were sub cultured onto Mannitol salt agar (Himedia) and incubated for 24 to $48 \mathrm{hrs}$ and examined for bacterial growth and typical colour change of media. Isolates were further examined by conventional methods including colony morphology, Gram's staining and biochemical tests to ascertain their identity as $S$. aureus.

Table 1. Details of Primers used for amplification of virulence genes of Staphylococcus aureus.

\begin{tabular}{|c|c|c|c|}
\hline Gene & Primer Sequence & Product Size & Refrence \\
\hline nuc & $\begin{array}{l}\text { F-GCGATTGATGGTGATACGGTT } \\
\text { R-AGCCAAGCCTTGACGAACTAAAGC }\end{array}$ & $270 \mathrm{bp}$ & Brakstadet al. (1992) \\
\hline clfA & $\begin{array}{l}\text { F-AAAACACGCAATTCGAAAA } \\
\text { R-GCAGTTGAAGTTACACCATTTAAGT }\end{array}$ & $855 \mathrm{bp}$ & Isabelle et al. (2011) \\
\hline $\operatorname{lukM}$ & $\begin{array}{l}\text { F-CGAGACCAAGATTCAACAAG } \\
\text { R-AAAGAAAACCACTCACATCA }\end{array}$ & $792 b p$ & Isabelle et al. (2011) \\
\hline $\operatorname{coa}$ & $\begin{array}{l}\text { F-AAATGATTCTTTATGCTCCG } \\
\text { R-AAAGCACATTGTCATGGTGA }\end{array}$ & $\begin{array}{l}970 \mathrm{bp} \\
730 \mathrm{bp}\end{array}$ & Gohet al. (1992) \\
\hline sea & $\begin{array}{l}\text { F-AAAATCAGATGGTAAAGGTTGGC } \\
\text { R-AGTTCTGCAGTACCGGATTTGC }\end{array}$ & $300 \mathrm{bp}$ & Isabelle et al. (2011) \\
\hline mecA & $\begin{array}{l}\text { F-GGGATGGCTTAATAACTCATACTT } \\
\text { R-CAGAGATGTGATGGAAAATAGTTGA }\end{array}$ & $310 \mathrm{bp}$ & Haran et al. (2012) \\
\hline hld & $\begin{array}{l}\text { F-GGGATGGCTTAATAACTCATACTT } \\
\text { R-CAGAGATGTGATGGAAAATAGTTGA }\end{array}$ & $236 b p$ & Isabelle et al. (2011) \\
\hline
\end{tabular}


Table 2. Cyclic conditions for PCR amplification of $S$. aureus virulent genes.

\begin{tabular}{|c|c|c|c|c|c|c|}
\hline Gene & Initial Denaturation & Denaturation & Annealing & Extension & Final Extension & No. of cycles \\
\hline clfA & $94^{\circ} \mathrm{C} / 5 \mathrm{~min}$ & $94^{\circ} \mathrm{C} / 30 \mathrm{sec}$ & $52^{\circ} \mathrm{C} / 40 \mathrm{sec}$ & $72^{\circ} \mathrm{C} / 40 \mathrm{sec}$ & $72^{\circ} \mathrm{C} / 7 \mathrm{~min}$ & 35 \\
\hline hld & $94^{\circ} \mathrm{C} / 5 \mathrm{~min}$ & $94^{\circ} \mathrm{C} / 30 \mathrm{sec}$ & $52^{\circ} \mathrm{C} / 40 \mathrm{sec}$ & $72^{\circ} \mathrm{C} / 40 \mathrm{sec}$ & $72^{\circ} \mathrm{C} / 7 \mathrm{~min}$ & 35 \\
\hline $\mathrm{SeO}$ & $94^{\circ} \mathrm{C} / 5 \mathrm{~min}$ & $94^{\circ} \mathrm{C} / 30 \mathrm{sec}$ & $52^{\circ} \mathrm{C} / 40 \mathrm{sec}$ & $72^{\circ} \mathrm{C} / 40 \mathrm{sec}$ & $72^{\circ} \mathrm{C} / 7 \mathrm{~min}$ & 35 \\
\hline lukM & $94^{\circ} \mathrm{C} / 5 \mathrm{~min}$ & $94^{\circ} \mathrm{C} / 30 \mathrm{sec}$ & $52^{\circ} \mathrm{C} / 40 \mathrm{sec}$ & $72^{\circ} \mathrm{C} / 40 \mathrm{sec}$ & $72^{\circ} \mathrm{C} / 7 \mathrm{~min}$ & 35 \\
\hline mecA & $94{ }^{\circ} \mathrm{C} / 5 \mathrm{~min}$ & $95^{\circ} \mathrm{C} / 30 \mathrm{sec}$ & $57^{\circ} \mathrm{C} / 30 \mathrm{sec}$ & $72^{\circ} \mathrm{C} / 1 \mathrm{~min}$ & $72^{\circ} \mathrm{C} / 5 \min$ & 30 \\
\hline coa & $95^{\circ} \mathrm{C} / 2 \mathrm{~min}$ & $95^{\circ} \mathrm{C} / 30 \mathrm{sec}$ & $58^{\circ} \mathrm{C} / 2 \mathrm{~min}$ & $72^{\circ} \mathrm{C} / 4 \mathrm{~min}$ & $72^{\circ} \mathrm{C} / 7 \mathrm{~min}$ & 40 \\
\hline
\end{tabular}

DNA isolation: The template DNA was prepared by boiling and snap chill method. Briefly, purified individual colony from Mannitol Salt Agar (Hi-Media, India) was dissolved in $150 \mu \mathrm{l}$ sterile double distilled water in microcentrifuge tubes. The tubes were kept in water bath set at $100{ }^{\circ} \mathrm{C}$ for $10 \mathrm{~min}$ and then in crushed ice for $20 \mathrm{~min}$. The tubes were then centrifuged at $10000 \mathrm{~g}$ for $5 \mathrm{~min}$ and the supernatant collected was used as template. The concentration and purity of the extracted DNA was checked using spectrophotometer and stored at $-20^{\circ} \mathrm{C}$ until use.

Identification of $S$. aureus by using species specific PCR: The isolates identified by cultural and biochemical methods as S.aureus were genetically confirmed by amplification of species specific nuc gene by PCR using Forward 5'GCGATTGATGGTGATACGGTT3' and Reverse 5'AGCCAAGCCTTGACGAACTAAAGC3' primers (Brakstadet al., 1992). The reaction consisted of $2.0 \mu \mathrm{l}$ template DNA, $2.5 \mu \mathrm{l}$ of $10 \mathrm{X}$ buffer, $0.2 \mu \mathrm{l}$ of $25 \mathrm{mM}$ dNTP mix, $1 \mathrm{U}$ of Taq DNA Polymerase (Fermentas Life Sciences), $\mathrm{MgCl}_{2}$ was used at 2.0 $\mathrm{mM}$ concentration and sterile distilled water. Amplification was carried out with initial denaturation at $94{ }^{\circ} \mathrm{C}$ for $5 \mathrm{~min}$, followed by 35 cycles of denaturation at 94 ${ }^{\circ} \mathrm{C}$ for $1 \mathrm{~min}$, annealing at $55^{\circ} \mathrm{C}$ for $30 \mathrm{sec}$, extension at $72{ }^{\circ} \mathrm{C}$ for $1 \mathrm{~min}$ and final extension at $72{ }^{\circ} \mathrm{C}$ for 7 $\min$.

Virulence gene detection: DNA amplification of virulence genes encoding forclumping factor $(c l f A)$, delta

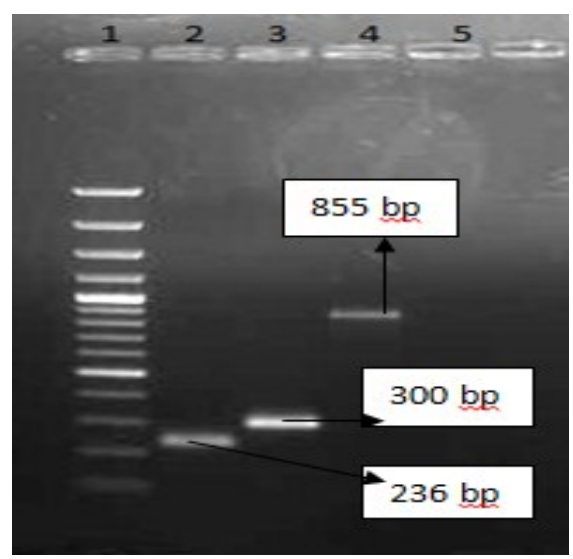

Fig. 5. Agrose gel electrophoresis of PCR amplicon of clfA, hld, and seogene of S. aureus isolates. Lane 1: DNA marker, Lane 2: Sample Positive for hldgene (236 bp), Lane 3: Sample Positive for seogene (300 bp) and Lane 4: Sample positive for clfAgene $(855 \mathrm{bp})$. haemolysin $(h l d)$, leukocidin (lukM), enterotoxin $\mathrm{O}$ (seo), coagulase ( $\mathrm{coa}$ ), and methicillin resistance gene ( $m e c A$ ) was carried out using PCR. Details of oligonucleotide primers used in the present study are mentioned in Table 1. All the reactions were performed in a final volume of $25 \mu \mathrm{l}$ of mixture containing $2.5 \mu \mathrm{l}$ of 10X PCR buffer, $2 \mu \mathrm{l}$ of $25 \mathrm{mM} \mathrm{Mgcl} 2,25 \mathrm{mM}$ of each of dNTP, 20 pmol of each gene-specific primers, $1 \mathrm{U}$ of TaqDNA Polymerase (Fermentas Life Sciences) and $2 \mu \mathrm{l}$ of template. The cyclic conditions for each reaction are given in Table 2. The PCR assays were performed in Gene Amp PCR System 2400 thermal cycler (Applied Biosystems, Foster City, CA, USA).

Visualization of amplicons: Amplified products were electrophoresed in a 1-1.5\% agarose gel containing ethidium bromide and visualized by trans-illumination under UV and photographed with Gel Documentation System (BioSpectrum 500 Imaging System, UVP, UK).

Antibiogram: Antimicrobial Susceptibility testing of the bacteria was performed with 15 antibiotics with disc diffusion method on Muller-Hinton agar according to the guidelines of Clinical and Laboratory Standards Institute (CLSI., 2008). The following antimicrobials obtained from HiMedia, (Mumbai) were used: Chloramphenicol (30 mcg), Gentamicin (30 mcg), Vancomycin $(10 \mathrm{mcg})$ Cefotaxime $(30 \mathrm{mcg})$, Amoxycillin with Clavulanic acid (30/10 mcg) Oxytetracycline (10 mcg) Kanamycin (30 mcg), Erythomycin (5 $\mathrm{mcg})$, Amikacin (10 mcg), Ampicillin (2 mcg), Sulphadiazine $(300 \mathrm{mcg})$, Ceftriaxone $(30 \mathrm{mcg})$, Streptomycin (10 mcg), Enrofloxacin (5 mcg) and Methicillin (10 mcg). The $S$. aureus ATCC 25923 was used as a quality control standard. The interpretation of the isolates as sensitive, intermediate sensitive and resistant was carried out as per the manufacturer's instructions.

\section{RESULTS AND DISCUSSION}

Prevalence of $S$. aureus strains in bovine mastitis: Among 250 samples collected, 70 isolates revealed colonies typical for $S$. aureus which were later confirmed by PCR amplification of the nuc gene which produced an amplicon of $270 \mathrm{bp}$ (Fig. 1). The $S$. aure$u s$ infection was more prevalent in unorganized farms which accounted to be $31.33 \%$ in contrast to organized farms which accounted for $23 \%$.

Virulence genes: PCR amplification of clfAgene resulted in single amplicon of 855 bp for 57 S.aureus isolates (Fig. 5). However, in case of coagene, 50 sam- 


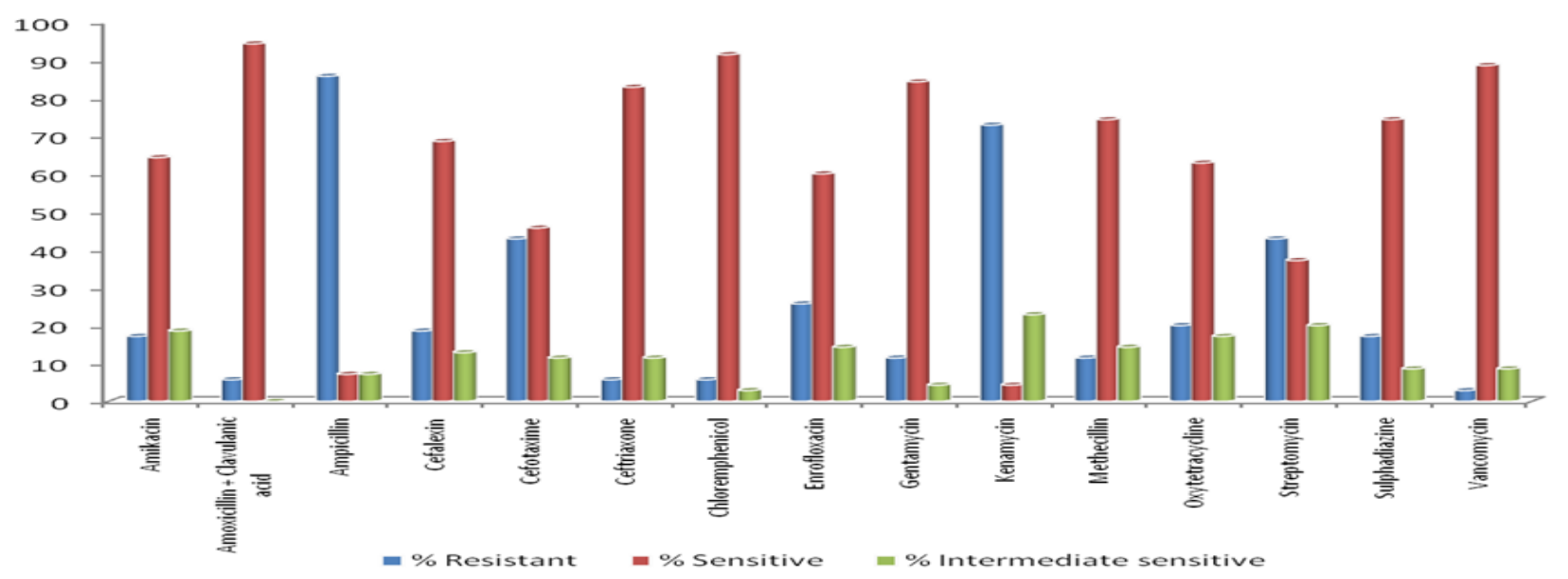

Fig. 6. Graphical representation of antibiotic sensitivity/resistance pattern of Staphylococcus aureus isolates

ples were positive and yielded two different products of $910 \mathrm{bp}$ and $730 \mathrm{bp}$ for 38 and 12 isolates respectively (Fig. 4). Amplification of hld gene produced an amplicon of $236 \mathrm{bp}$ in 43 isolates (Fig. 5) and 49 isolates showed an amplicon of $792 \mathrm{bp}$ for lukMgene (Fig. 3). Amplification of seo gene yielded an amplicon of $300 \mathrm{bp}$ for 38 isolates (Fig. 5). A total of 20 out of 70 isolates possessed mecAgene by depecting an amplicon of 310 bp (Fig. 2).

Antibiogram: A wide range of susceptibility to antimicrobials was observed among $S$. aureus isolates. Out of the 70 isolates $94.28 \%$ were sensitive to a combination of Amoxicillin and clauvinic acid. This was followed by Chloramphenicol (91.4\%), Vancomycin $(88.57 \%)$, Gentamycin $(84.2 \%)$, Ceftriaxone $(82.8$ $\%)$, Methicillin (72.85\%), Cephalexin (68\%), Amikacin $(61.42 \%)$ Enrofloxacin $(60 \%)$, Oxytetracycline (62.8\%). High resistance was recorded against Ampicillin $(85.7 \%)$ which was followed by Kanamycin (71.42 \%) Cefotaxime (54.28) and Sulphadizine (51.48), Streptomicin (42\%). (Fig 6) Twenty isolates were found to be methicillin-resistant, while the remaining (50) were methicillin-susceptible. All the MRSA isolates were positive for mecA gene.

Worldwide, mastitis has been reported to be one of the most common infectious disease affecting dairy cows and the most economically important disease of dairy industry. Since $S$. aureus is the most frequently isolated agent in mastitis cases all over the world, it is important to reveal virulence factors helping in pathogenesis and antimicrobial resistance pattern of the organism to develop effective control strategies against mastitis caused by $S$. aureus. The present study was therefore focused to detect some of the virulence factors and susceptibility pattern of the $S$. aureus isolated from bovine mastitis milk samples in Kashmir province. S. aureus are classically identified by conventional methods that are time consuming and expensive and they leave a situation of ambiguity because of variability showed by different strains. More recently, PCR based methods involving amplification of species -specific genes, like nuc gene have been used for identification of $S$. aureus. The nuc gene based PCR has been widely used for identification of $S$. aureus .Yamagishiet al. (2007) and Kuzma et al. (2003) have used nuc gene amplification as a tool for the identification of $S$. aureus in mastitic milk.

In the present study seventy samples were positive for S. aureus, indicating an occurrence of $28 \%$ bovine mastitis in Kashmir Valley. Ranjan et al. (2011) has reported occurrence of $27.37 \%$ for $S$. aureus from bovine mastitis in Jharkhand, India andBotrelet al. (2010) has reported a prevalence of $30.2 \%$ for $S$. aure$u s$ from clinical and subclinical mastitic dairy cows in Rhone-Alpes, France. The reports suggest high prevalence pattern of S.aureus in bovine mastitic milk in India and abroad.

The binding of an organism to the host cell is an important factor for pathogenesis. The ability of $S$. aureus to adhere to extracellular matrix proteins is thought to be essential for colonization and establishment of infections (El.sayed et al., 2005). Presence of 57 positive clfA samples indicates probable important role of these elements in the pathogenicity of bovine mastitis. Similarly, more than $50 \%$ of the isolates studied were positive forlukM gene which is highly cytotoxic on bovine neutrophils (Barrio et al., 2006). It's a family of pore-forming toxins which may be involved with escape from the phagosome after phagocytosis and intracellular survival, which is an important trait for the maintenance of $S$. aureus intramammary infection (Dego et al., 2002).

In the present study, screening of $S$. aureus isolates for the presence of coa virulence gene has revealed that 50 of the $70(71.4 \%)$ isolates carried the gene. All the positive isolates showed a single amplicon but of two different sizes, $970 \mathrm{bp}$ and $730 \mathrm{bp}$. This finding is in agreement with that of Momtaz et al. (2011), who carried out coa gene amplification from bovine mastitic samples. From $86 \mathrm{~S}$. aureus isolates, they found 31 isolates to amplify $970 \mathrm{bp}$ fragment, and 11 isolates to amplify $730 \mathrm{bp}$ through PCR amplification. Analysis of coagulase-encoding Staphylococcus aureus DNA 
(coa) genes has demonstrated variable sequences in the 32 -end coding region. This region contains a polymorphic repeat region that can be used to differentiate S.aureus isolates (Guler et al., 2005).

During the progression of infection, S.aureus can produce superantigenic toxins including staphylococcal enterotoxins (SEs), their interest reside not only in their potential role in staphylococcal diseases by modulating the host immune response contributing to maintain a suitable environment for colonization (Omoe et al., 2002) but also in their ability to cause food poisoning. The fact that 38 isolates $(54.28 \%)$ in this study harbored this super antigenic gene suggests that mastitis due to S.aureus might represent a risk for human health due to presence of these enterotoxins in milk.

In the present investigation, $61 \%$ of the isolates possessed hldgene. Contrary to this in Finland and Spain, Haveri et al., (2007) and Fueyo et al., (2005) found hld gene present in $88.8 \%$ and $84 \%$ of $S$. aureus isolates of bovine mastitis, respectively. Delta haemolysin is recognized to have detergent action on cell membranes resulting in cell lysis (Marconi et al., 2005).

Emergence of antimicrobial resistance among animal pathogens is of growing concern in veterinary medicine as it renders antimicrobials ineffective for treating the animals. In addition, the antimicrobial resistance in zoonotic pathogens, like $S$. aureus possess a potential risk for human health too. In Methicillin resistant $S$. aureus (MRSA), the resistance to antibiotics is caused by an altered penicillin-binding protein, which makes it resistant to all $\beta$-lactam antimicrobials. The $m e c A$ gene encodes for this protein and is therefore widely used to identify MRSA. S. aureus isolates were screened for mecA gene by PCR and it was found that $28.57 \%$ were positive for the gene. All the isolates which were positive for $m e c A$ gene were phenotypically resistance to methicillin, whereas sensitive and intermediate sensitive isolates for methicillin were devoid of the $m e c A$ gene.

The antibiogram profile in the present study indicated that Amoxicillin with Clauvinic acid, Chloramphenicol, Vancomycin, Gentamycin, were most effective antimicrobials, whereas Ampicillin, Kanamycin, Cefotaxime, Sulphadizine and Streptomicin was least effective against $S$. aureus. Majority of investigators have presented different results, but some agreement has also been found with present study Turutoglu et al. (2006) and Malinowski et al. (2008) reported $97.4 \%$ and $93.2 \%$ of $S$. aureus isolates sensitive to amoxicillin and clavulanic acid, respectively. LI et al. (2009) and Khakpoor et al. (2011) recorded maximum resistance to ampicillin in $S$. aureus isolates from bovine mastitis. The long indiscriminate use of Ampicillin would have been responsible for development of resistance towards this antibiotic (Gitau et al., 2011) whereas the Amoxicillin with Clauvinic acid antibiotic is relatively less used for treating mastitis (Horodyska et al., 2012) and thus most effective. The regular monitoring of antimicrobial susceptibility of S.aureus will not only result in the use of right antibiotic for control of S.aureus infections but will also help in avoiding the development of multiple drug resistant strains of S.aureus. Same is also true for all other microbes involved in various diseases and infections in humans and animals.

\section{Conclusion}

To our knowledge, this is the first report of genotypic characterization and antibiogram in Staphylococcus aureus strains isolated from bovine mastitis in Kashmir. Parameters of this study suggest that there is a broad distribution of closely related $S$. aureus clones which are responsible for the mastitis situation in Kashmir. Difference found in the gene patterns and antibiogram provided a better understanding of the distribution of the prevalent S.aureus clones among bovine mastitis isolates. Therefore, determining the virulence gene profile and antibiogram of S.aureus isolates from bovine mastitis will be helpful in devising strategies for therapeutic intervention and control of mastitis.

\section{REFERENCES}

Bansal, B. K. and Gupta, D .K. (2009). Indian journal of dairy science, 67: 337-345

Barrio, M. B., Rainard, P. and Prevost, G. (2006). LukM/ $L u k F^{\prime}-P V$ is the most active Staphylococcus aureus leukotoxin on bovine neutrophils. Microbes and Infection., 8: 2068-74

Booth, M. C., Pence, L. M., Mahasreshti, P., Callegan, M., and Gilmore, M. (2001). Clonal associations among Staphylococcus aureus isolates from various sites of infections. Infection and Immunity, 69: 345-352

Botrel, M. A., Haenni, M., Morignat, E., Sulpice., Madec, J. Y. and Calavas, D. (2010). Distribution and antimicrobial resistance of clinical and subclinical mastitis pathogens in dairy cows in Rhône-Alpes, France. Food borne Pathogens and Disease, 7: 479-487

Brakstad, O. G., Aasbakk, K. and Maeland, J. A. (1992). Detection of Staphylococcus aureus by polymerase chain reaction amplification of the nuc Gene. Journal of Clinical Microbiology, 30: 1654-1660

CLSI. Performance Standards for Antimicrobial Disk and Dilution Susceptibility for Bacteria Isolated from Animals; Approved Standard - Second Edition. CLSI document M31-A3,28: 65-72. Wayne, PA, USA: Clinical and Laboratory Standards Institute, 2008.

Dego, K., Vandijk, J. E. and Nederbragt, H. (2002). Factors involved in the early pathogenises of Bovine Staphylococcus aureus mastitis with emphasis on bacterial adhesion and invasion. Veterinary Quarterly, 24: $181-198$

Dhanda, M. R. and Sethi, M. S. (1962): Investigation of Mastitis in India.Icar Res. Series 35, New Delhi, India.

Dinges, M. M, Orwin, P. M. and Schlievert, P. M. (2000). Exotoxins of Staphylococcus aureus.Journal of Clinical 
Microbiology, 13: 16-34

Dua, K. (2001): Incidence, etiology and estimated economic losses due to mastitis in Punjab and in India-An update. Indian Dairyman, 53: 41-48

EL-sayed, A., Alber, J., Lammler, C., Bonner, B., Huhn, A., Kaleta, E. F. and Zschock, M. (2005). PCR-based detection of genes encoding virulence determinants in Staphylococcus aureusfrom birds. Journal of veterinary medicine.B. Infectious Diseases and Veterinary Public Health, 52: 38-44

Fueyo, J. M., Mendoza, M. C., Rodicio., Muniz, M. R. J., Alvarez, M. A. and . Martín, M. C. (2005).Cytotoxin and Pyrogenic Toxin Superantigen Gene Profiles of Staphylococcus aureus Associated with Subclinical Mastitis in Dairy Cows and Relationships with Macro restriction Genomic Profiles. Journal of Clinical Microbiology, 43: 1278-1284.

Gitau, G. K., Wabacha, J. K., Mulei, C., Mndurumo, S. and Nduhiu, J. M. (2011). Isolation rates and antimicrobial sensitivity patterns of bovine mastitis pathogens in peri-urban area of Nairobi, Kabete, Kenya.Ethiopian Veterinary Journal, 15: 1-13

Goh, S. H., Byrne, S. K., Zhang, J. L. and Chow, A. W. (1992). Molecular typing of Staphylococcus aureus on the basis of coagulase gene polymorphisms. Journal of Clinical Microbiology, 30: 1642-1645

Guler, L., Ok, U., Gunduz, K., Gulcu, Y. and Hadimli, H. S. (2005). Antimicrobial susceptibility and coagulase gene typing of Staphylococcus aureus isolated from bovine clinical mastitis cases in Turkey. Journal of Dairy Science, 88: 3149-3154

Haran, K. P., Godden, S. M., Boxrud, D., Jawahir, S. Bender, J. B. and Sreevatsan, S. (2012). Prevalence and Characterization of Staphylococcus aureus, Including Methicillin-Resistant Staphylococcus aureus, Isolated from Bulk Tank Milk from Minnesota Dairy Farms. Journal of Clinical Microbiology, 50: 688-695

Haveri, M., Roslof, A., Rantala, L. and Pyarala, S. (2007) Virulence genes of bovine Staphylococcus aureus from persistent and non-persistent intramammary infections with different clinical characteristics. Journal of $\mathrm{Ap}$ plied Microbiology, 103:993-1000

Horodyska, M. M., Kubiak, J., Lassa, H. and Malinowski, E. (2012). Changes in antibiotic susceptibility pattern of atypical Staphylococcus aureus strains isolated from cows of the same herd in 2008-2010. Bulletin of the Veterinary Institute in Pulawy, 56: 139-14

Hussain, A., Shakoor, A., Yousaf, A., Rehman, S. U. and Zaman, M. A. (2012). Clinical and subclinical Staphylococcus auerus in dairy buffaloes: disease characteristics and antibiotic susceptibility profiles of isolates. The Journal of Animal and Plant Sciences, 22: 217-220

Kalorey, D. R., Shanmugam, Y., Kurkure, N. K., Chousalkar, K. K., and Barbuddhe, S. B. (2007). PCR-based detection of genes encoding virulence determinants in Staphylococcus aureus from bovine subclinical mastitis cases. Journal of Veterinary Science, 8: 151-154

Khakpoor, M., Safarmashaei, S. and Jafary, R. (2011). Study of Milk Extracted from Cows Related to Staphylococcus aureus by Culturing and PCR. Global Veterinaria,7: 572-575
Kumar, R., Yadav, B. R. and Singh, R. S. (2010). Genetic Determinants of antibiotic resistance in Staphylococcus aureus isolates from milk of mastitic crossbred cattle. Current Microbiology, 60: 379-386

Kuzma, K., Malinowski, E., Lassa, H. and Kłossowska, A. (2003). Specific detection of Staphylococcus aureus by PCR in intramammary infection.Bulletin of the Veterinary Institute in Pulawy, 47: 183-190

Lee, J. H. (2003). Methicillin (oxacillin)-resistant Staphylococcus aureus strains isolated from major food animals and their potential transmission to humans. Applied and Environmental Microbiology, 69: 6489-6494

Li, J., Zhou, H., Yuan, L., He, T. and Hu, S. (2009). Prevalence, genetic diversity, and antimicrobial susceptibility profiles of Staphylococcus aureus isolated from bovine mastitis in Zhejiang Province, China. Journal of Zhejiang University-Science B,10:753760

Malinowski, E., Lassa, H., Smulski, S., Kłossowska, A. and Kaczmarowski, M. (2008). Antimicrobial susceptibility of bacteria isolated from cows with mastitis in 2006-2007.Bulletin of the Veterinary Institute in Pulawy, 52: 565-572

Marconi, C., Cunha, M. L. R. S., Araujo, J. P., Jr. and Rugolo, L. M. S. S. (2005). Standardization of the PCR technique for the detection of delta toxin in Staphylococcus spp. Journal of Venomous Animals and Toxins Including Tropical Diseases, 11:117-128

Momtaz, H., Tajbakhsh, E., Rahimi, E. and Momeni, M. (2011). Coagulase gene polymorphism of Staphylococcus aureus isolated from clinical and sub-clinical bovine mastitis in Isfahan and Chaharmahalva Bakhtiari provinces of Iran. Comparative Clinical Pathology, 20:519522

NDDB, (2012). National Dairy Development Board (NDDB). Annual Report, 2011-12.

Omoe, K., Ishikawa, M., Shimoda, Y., Hu, D. L., Ueda, S. and Shinagawa, K. (2002). Detection of seg, seh, and sei genes in Staphylococcus aureus isolates and determination of the enterotoxin productivities of $S$. aureusisolates harboring seg, seh, or sei genes. Journal of Clinical Microbiology, 40:857-862

Ote, I., Taminiau, B., Duprez, J.N. Dizier, I. andMainil, J. G. (2011). Genotypic characterization by polymerase chain reaction of Staphylococcus aureus isolates associated with bovine mastitis. Veterinary Microbiology, 153: 285-292

Ranjan, R., Gupta, M. K. and Singh, K. K. (2011). Study of bovine mastitis in different climatic conditions in Jharkhand, India. Veterinary World, 4: 205-208.

Turutoglu, H., Ercelik, S. and Ozturk, D. (2006). Antibiotic resistance of Staphylococcus aureusand Coagulase negative Staphylococci isolated from bovine mastitis. Bulletin of the Veterinary Institute in Pulawy, 50:41-45

Wang, G. Y. and Niu, Z. N. (2009). Isolation and identification of pathogenic bacteria to clinical mastitis in liaochen city.Journal of Shandong Agriculture University

Yamagishi, N., Jinkawa, Y., Omoe, K., Makino, S. and Oboshi, K. (2007). Sensitive test for screening for Staphylococcus aureus in bovine mastitis by broth cultivation and PCR. Veterinary Record, 16: 381-383 